Waldemar Szczerbiński

Uniwersytet im. Adama Mickiewicza w Poznaniu heschel@poczta.onet.pl

ORCID: 0000-0003-2946-7352

DOI: http://dx.doi.org/10.12775/BPTh.2020.014
Biblica

et

Patristica

Thoruniensia

13 (2020) 3: 325-339

ISSN (print) $1689-5150$

ISSN (online) 2450-7059

\title{
Szabat jako celebracja czasu w nauczaniu A.J. Heschela*
}

\section{Shabbat as a celebration of time in A.J. Heschel's teaching}

Streszczenie. Przedmiotem analiz w tym artykule jest żydowski święty dzień - szabat, który z niezwykłym kunsztem i głębią został przedstawiony przez Abrahama Joshuę Heschela głównie w dziele Szabat i jego znaczenie dla współczesnego człowieka. Ta książka pięknie opisuje rabiniczne, kabalistyczne i chasydzkie rozumienie doświadczenia szabatu. Autor umiejętnie wiąże tu stare i czcigodne dziedzictwo żydowskie z sytuacją współczesnych ludzi. W tym dziele Heschel wypracował jeden z głównych motywów swojej myśli - ideę świętości w czasie. Żydowski autor rozumie judaizm jako religię czasu i wskazuje istotę oraz znaczenie czasu w życiu pojedynczego Żyda i całej wspólnoty. Heschel nie tyle przekonuje do idei szabatu, nie tyle dowodzi konieczności przestrzegania świętości tego dnia, co raczej ukazuje jego sens i sposób celebracji. Jak dowodzi Rabin, w przeżywaniu szabatu nie chodzi o zwykłe powstrzymywanie się od aktywności fizycznej, ale o osiągniecie właściwego stanu ducha, o „zakosztowanie” zbawczej rzeczywistości. Przestrzeganie Szabatu to nie tylko powstrzymywanie się od pracy, lecz także stwarzanie menuchy, odpoczynku, który jest także celebracją. Konkretne przykazania odnoszące się do celebrowania szabatu służą po prostu wypełnieniu micwy. Dla Heschela bowiem micwa to „modlitwa w formie czynu”. W publikacji kolejno omówię: świętość szabatu w rozumieniu Heschela, proponowane przez niego drogi uświęcenia i uwiecznienia tego dnia oraz właściwy sposób celebracji.

Abstract. The subject of the analysis in this article (Shabbat as a celebration of time in A.J. Heschel's teaching) is the Jewish holy day - the Sabbath, which was described with unusual skill and depth by Abraham Joshua Heschel mainly in the work The Sabbath: Its Meaning for Modern Man. This book beautifully describes the rabbinical,

* Abraham Joshua Heschel (1907-1972) - do najważniejszych prac Heschela zalicza się: Man Is Not Alone: A Philosophy of Religion (1951), God in Serach of Man: A Philosophy of Judaism (1955), The Prophets (1962), The Sabbath: Its Meaning for Modern Man (1951) pierwszy polski przekład dokonany przez $\mathrm{H}$. Halkowskiego ukazał się w wydawnictwie Atext (1994). Obszerne opracowanie na temat Heschela i jego twórczości zob: W. Szczerbiński, Abrahama Joshuy Heschela filozofia człowieka. 
Kabbalistic and Hasidic understanding of the Sabbath experience. The author skillfully links here the old and venerable Jewish heritage with the situation of modern people. In this work, Heschel developed one of the main motives of his thought - the idea of holiness in time. He presents Judaism as a religion of time and indicates the essence and significance of time in the life of an individual Jew and entire communities. Heschel is not so much convincing about the idea of the Sabbath, it is not so much proof of the need to observe the sanctity of the day, but rather shows its meaning and manner of celebration. As the Jewish Rabbi argues, experiencing the Sabbath is not about merely abstaining from physical activity, but about achieving the right state of spirit, trying to "testing" of saving reality. Observing the Sabbath is not only abstaining from work, but also creating a menucha, rest, which is also a celebration. Specific commandments regarding the Sabbath celebration are simply used to fulfill the mitzvah, because for Heschel mitzvah is "prayer in the form of an act". The publication will sequentially present: the Sabbath holiness as understood by Heschel, his ways of sanctifying and making eternal that day, and the proper way of celebration.

Słowa kluczowe: A.J. Heschel; judaizm; szabat; czas; celebracja.

Key words: A.J. Heschel; Judaism; Sabbath; time; celebration.

\section{Córka rabina Heschela wspomina:}

Szabat był czasem, kiedy moi rodzice przyjmowali gości, zwykle podczas kolacji szabatowej w piątek wieczór albo na podwieczorek z kolacją o godzinie czwartej w sobotnie popołudnie [...]. Mój ojciec zmarł właśnie w szabat. Planowaliśmy iść razem do synagogi w sobotę 23 grudnia 1972 roku, ale on się nie obudził. W tradycji żydowskiej pełną pokoju śmierć w czasie snu uważa się za oznakę wielkiej pobożności, jeszcze większej, jeśli śmierć następuje w Szabat. Taka śmierć nosi miano pocałunku Boga ${ }^{1}$.

Wśród współczesnych myślicieli żydowskich trudno odnaleźć kogoś bardziej odpowiedniego niż Heschel, kto z takim kunsztem i głębią wyjaśniłby prawdę o szabacie. Susannah Heschel stwierdza:

Książka mojego ojca o szabacie, jedno z najpopularniejszych jego pism, przywołuje ducha, który stworzył on wraz z moją matką w naszym domu, w którym Szabat był

1 A.J. Heschel, Człowiek szukający Boga, s. 39-40 (Wstęp napisany przez córkę Susannah Heschel). 
pełen wyciszenia i przepełniony atmosferą świętowania. Ta książka pięknie opisuje rabiniczne, kabalistyczne i chasydzkie rozumienie doświadczenia Szabatu ${ }^{2}$.

Tytuł i podtytuł książki The Sabbath: Its Meaning for Modern Man odzwierciedla to, co było typowym przedsięwzięciem Rabina, tj. wiązanie starego i czcigodnego dziedzictwa żydowskiego - szabatu z sytuacją współczesnych ludzi ${ }^{3}$. W tym dziele Heschel wypracował jeden z głównych motywów swojej myśli - ideę świętości w czasie. Rabin przedstawia judaizm jako religię czasu i wskazuje istotę oraz znaczenie czasu w życiu pojedynczego człowieka i całych społeczności.

Dlaczego Heschel napisał ową książkę? Jak utrzymuje jego córka,

Szabat pojawił się w czasie, gdy amerykańscy Żydzi radykalnie się asymilowali i gdy wielu zawstydzało publiczne wyrażanie żydowskości. Nawet wśród rabinów i żydowskich przywódców odrzucenie żydowskiego mistycyzmu, chasydyzmu, a nawet teologii było powszechne. Wydawało się, że pragną bezreligijnego judaizmu - judaizmu bez Boga, wiary i przekonań. Szabat przeszkadzał im w pracy, życiu towarzyskim, robieniu zakupów i po prostu w byciu Amerykanami [...]. Próbując przedstawić na nowo wagę Szabatu, mój ojciec nie ganił Żydów za ich lekceważenie [...]. Podkreślał, że Szabat nie dotyczy psychologii ani socjologii, nie służy do tego, aby uczynić nas spokojniejszymi, czy do umocnienia rodzinnych więzów. Nie uważał też, że Szabat łączy się z odrzuceniem nowoczesności czy świeckiego świata - dla niego Szabat był dopełnieniem budowania cywilizacji, a nie ucieczką od niej ${ }^{4}$.

Właściwe przeżywanie szabatu warunkuje zarówno życie tu i teraz, jak i życie wieczne. „To, czym jesteśmy, zależy od tego, czym Szabat jest dla nas”5. Na pytanie, czym jest szabat, Heschel odpowiadał: „Przypomnieniem o wierności każdego człowieka; zniesieniem różnicy między panem a niewolnikiem, bogatym i biednym, powodzeniem i niepowodzeniem. Świętować szabat oznacza doświadczać najgłębszej niezależności od cywilizacji i społeczeństwa, od sukcesów i niepokoju"6.

2 A.J. Heschel, Moral Grandeur and Spiritual Audacity, s. xxix.

3 Zob. F. Sherman, The Promise of Heschel, s.19.

4 A.J. Heschel, Szabat, s. 14-15.

5 Ibidem, s. 19.

6 A..J. Heschel, Bóg szukający człowieka, s. 516. 


\section{1. Świętość szabatu}

Współczesny człowiek na ogół nie uwzględnia w swojej refleksji idei świętości. Ta kategoria jest całkowicie obca nie tylko nauce, ale nawet współczesnej filozofii. Pojawia się jedynie $\mathrm{w}$ dysputach teologicznych lub w badaniach religioznawczych. To pojęcie wydaje się pozbawione jakiejkolwiek racjonalności i nie przystaje do nowożytnego dyskursu. Jeśli się pojawia, to jedynie w kontekście czegoś symbolicznego lub tajemniczego. Heschel nie zgadza się z takim podejściem. Przeciwnie, stwierdza, że „filozofia może dużo nauczyć się z Biblii. Dla filozofa idea dobra jest ideą najwznioślejszą. Dla Biblii idea dobra nie jest ostateczna; nie mogłaby ona istnieć bez świętości. Dobro jest podstawą - świętość jest szczytem. Rzeczy stworzone w ciągu sześciu dni uznał On za dobre, siódmy dzień uczynił On świętym"?.

W judaizmie zatem „świętość” jest traktowana jako główny aspekt codziennego życia, jako podstawa wszelkiego dobra, która nieustannie ogarnia całą rzeczywistość ${ }^{8}$. Od czasu powstania judaizmu, przez cały okres jego rozwoju, pojęcie świętości było jego podstawową doktryną. Judaizm rozróżnia dwa typy świętości: świętość związaną z rytuałami, miejscami, osobami lub rzeczami, która jest określana jako świętość kapłańska lub zewnętrzna, oraz świętość etyczną lub moralną. Świętość rytualna jest rodzajem narzuconej świętości. To zależy od rozporządzeń, proklamacji i deklaracji. Ten rodzaj świętości nie wynika $\mathrm{z}$ istoty rzeczy. Idea świętości w sensie etycznym wypływa natomiast z najgłębszej istoty, z jakości samych rzeczy. Świętość etyczna oznacza po prostu doskonałość moralną.

Heschel przypomina, że starożytni rabini rozróżniali trzy aspekty świętości: „świętość Imienia Boga, świętość Szabatu i świętość Izraela”9. Przez świętość Izraela rozumiemy zarówno świętość ludu Izraela jako Narodu Wybranego jak i świętość ziemi Izraela jako miejsca danego Żydom przez Boga. Warto zwrócić uwagę, że owa Ziemia Obiecana została uświęcona przez ludzi, natomiast Szabat został uświęcony przez Boga. Jak widzimy, „wszystkie aspekty świętości są w tajemniczy sposób powiązane ze sobą"10.

W najszerszym znaczeniu świętość jest tylko innym określeniem imitatio Dei (naśladowania Boga), obowiązkiem wynikającym z bliskiej relacji człowieka z Bogiem. Najczęściej występującym imieniem Boga w literaturze rabinicz-

7 A.J. Heschel, Szabat, s. 126.

8 Zob. S. Umen, Jewish Concepts and Reflections, s. 42.

9 A.J. Heschel, Szabat, s. 134.

10 Ibidem, s. 135. 
nej jest „Święty”, dlatego Izrael nazywany jest również świętym. Ale świętość Izraela zależy od postępowania Ludu Wybranego w sposób, który byłby podobny do działania Boga. Stąd wezwanie: „Bądźcie świętymi, bo Ja jestem święty, Pan, Bóg wasz!" (Kpł 19,2).

Świętość, do której wzywali prorocy nie jest pojęciem metafizycznym, ale główną zasadą i źródłem etyki żydowskiej ${ }^{11}$. W religii żydowskiej etyka i świętość są ze sobą powiązane (to nie jest etyka dobra). Z żydowskiego punktu widzenia o etyce można mówić jedynie w perspektywie świętości, ponieważ etyka w judaizmie odnosi się do czynów, które są miłe, dobre, właściwe i godne w oczach Boga. Takie akty są jednocześnie uważane za święte, ponieważ intencjonalnie są odniesione do Boga lub też dokonywane ze względu na Boga. Dla religijnego człowieka wszystko ma charakter religijny. Jak przekonywał Heschel, „religia jest czymś więcej niż wyznaniem wiary lub doktryną, więcej niż ufnością lub pobożnością; jest wiecznym faktem we wszechświecie, czymś, co istnieje poza poznaniem i doświadczeniem, porządkiem bytu, świętym wymiarem egzystencji”" ${ }^{12}$. Szabat jest określany jako dzień święty, ponieważ najpełniej odzwierciedla ów porządek bytu. Przyczyna świętości szabatu leży po stronie Boga. „Szabat jest święty nie z łaski człowieka. To Bóg uświęcił siódmy dzień”13. Heschel przywołuje starożytną prawdę, która głosi: „Przyszły świat charakteryzuje ten sam rodzaj świętości, jaki na tym świecie posiada Szabat... Szabat posiada świętość podobną do świętości świata przyszłego"14. Właściwe przeżywanie szabatu daje człowiekowi możliwość uświęcania czasu ${ }^{15}$.

\section{Uświęcenie i uwiecznienie czasu}

Heschel wiele miejsca poświęca ukazaniu różnicy, jaka panuje między czasem a przestrzenią. Człowiek jest w stanie zapanować nad przestrzenią, lecz czas ustawicznie pozostaje dla niego nieujarzmiony i nieprzenikniony. Możemy pokonywać olbrzymie dystanse, ale nie jesteśmy w stanie ani odzyskać przeszłości, ani przeskoczyć do przyszłości. Choć człowiek przekracza przestrzeń, to jednak czas przekracza człowieka. Czas zatem jest największym wyzwaniem dla człowieka. Jak ujął to Heschel: „wszyscy uczestniczymy w procesji przez królestwo czasu, które jest nieskończone, ale nie jesteśmy w stanie go zdobyć

\footnotetext{
11 Zob. Ibidem, s. 44.

12 J. Neusner, N.M. Neusner (red.), An Anthology of Abraham Joshua Heschel, s. 38.

13 A.J. Heschel, Szabat, s. 127.

14 Ibidem, s. 123. Jest tu odniesienie do komentarza Mechilta do Księgi Wyjścia 31,17.

15 Por. A.J. Heschel, Szabat, s. 126.
} 
ani w nim osiąść" ${ }^{16}$. Czas jest poza naszym zasięgiem. Przestrzeń jest zależna od naszej woli, ponieważ możemy dowolnie kształtować i zmieniać rzeczy w przestrzeni. Na czas nie mamy wpływu. Jest on zarówno bliski, jak i daleki, nieodłącznie związany z ludzkim doświadczeniem i jednocześnie przekraczający wszelkie doświadczenie. Stąd główna teza Heschela, że „czas należy wyłącznie do Boga"17. Co wydaje się ciekawe, czas dzielimy z innymi, jedynie przestrzeń jest wyłącznie nasza własnością. Z powodu posiadana swojej przestrzeni jestem rywalem wszystkich innych bytów, natomiast z racji mojego życia w czasie jestem współuczestnikiem z wszystkimi innymi bytami. „Przechodzimy przez czas; zajmujemy przestrzeń" ${ }^{\prime 18}$.

Rabin dostrzega w egzystencji człowieka biegunowość procesów i zdarzeń. „Człowiek żyje w porządku zdarzeń, nie tylko w porządku procesów. To jest duchowy porządek. Momenty intuicji, momenty decyzji, momenty modlitwy mogą być nieistotne $\mathrm{w}$ świecie przestrzeni, a jednak to one sprawiają, że nasze życie staje się przedmiotem szczególnej troski"19. Procesy i zdarzenia różnią się między sobą w zasadniczy sposób. Według Heschela „procesy odbywają się regularnie, według stałych wzorów; wydarzenie jest wyjątkowe i nieregularne. Proces może być ciągły, pewny, jednolity; zdarzenia występują nagle, sporadycznie, okazjonalnie. Procesy są typowe; zdarzenia są wyjątkowe. Proces stosuje się do prawa; zdarzenie tworzy precedens" ${ }^{20}$. Innymi słowy, proces jest związany tylko z porządkiem fizycznym, a zdarzenie także z porządkiem duchowym. Żydowski myśliciel łączy porządek fizyczny z przestrzenią, natomiast porządek duchowy z czasem. Priorytet czasu w jego koncepcji wynika z priorytetu bycia, które ma charakter niesubstancjalny, duchowy. Tymczasem byt ludzki ma charakter substancjalny, a zatem z konieczności materialny.

Czas jest dla nas raczej środkiem do pomiarów niż sferą, w której przebywamy. Uświadamiamy go sobie dopiero wtedy, gdy zaczynamy porównywać dwa wydarzenia i zauważamy, że jedno jest późniejsze niż drugie; kiedy słuchamy dźwięków i wiemy, iż jedna nuta poprzedza inną. Podstawą dla świadomości czasu jest rozróżnienie między wcześniejszym i późniejszym. Czyż jednak czas jest tylko relacją pomiędzy wydarzeniami w czasie? Czy obecna chwila nie ma żadnego znaczenia niezależnego od jej stosunku do przeszłości? Ponadto, czy wiemy tylko o tym, co jest w czasie, jedynie o wydarzeniach oddziałujących na rzeczy przestrzeni? Jeśli

\footnotetext{
16 J. Neusner, N.M. Neusner (red.), An Anthology of Abraham Joshua Heschel, s. 75.

17 Ibidem, s. 76.

18 Ibidem.

19 A.J. Heschel, Who Is Man?, s. 43.

20 Ibidem, s. 42.
} 
zatem nie zdarzyło się nic, co ma związek ze światem przestrzeni, to czy nie było wtedy czasu? ${ }^{21}$.

Zdaniem Heschela potrzebna jest specjalna świadomość, by rozpoznać ostateczne znaczenie czasu. Świat przestrzeni otacza nasze istnienie. Jest on jednak jedynie częścią życia - resztą jest czas. „Rzeczy są brzegiem - podróż odbywa się w czasie”22. Jak ujmuje to Heschel, przestrzeń jest jakby „zamarzniętym czasem, natomiast wszystkie rzeczy - skamieniałymi wydarzeniami"23. Zazwyczaj istotą czasu jest dla nas przelotność, tymczasowość. Heschel jednak uważa, „iż fakt nietrwałości przychodzi nam na myśl właśnie wtedy, gdy rozmyślamy o rzeczach przestrzeni. To świat przestrzeni daje nam poczucie tymczasowości. Czas poza przestrzenią, niezależny od niej, jest wieczny; to czas przestrzeni ginie" 24 .

Dla żydowskiego myśliciela jest oczywiste, że świat bez czasu byłby światem bez Boga, światem istniejącym sam w sobie, bez odnowy, bez Stwórcy. Świat bez czasu byłby światem oderwanym od Boga, rzeczą samą w sobie, rzeczywistością bez realizacji. Istniejący świat został obdarzony czasem, który toczy się z woli Boga, i w ten sposób realizuje się nieskończony plan mający swój początek i koniec w Bogu. Nie zapanujemy nad czasem przez podbój przestrzeni, choćby w dalekim kosmosie. Problem czasu możemy rozwiązać tylko poprzez uświęcenie czasu. Dla człowieka bez Boga czas jest nieuchwytny; dla człowieka wierzącego czas jest „wiecznością w przebraniu”. Heschel wyraził ową prawdę w charakterystyczny i poetycki dla siebie sposób: „Świat stworzony jest językiem Boga, czas jest pieśnią Boga, a rzeczy w przestrzeni dźwiękami w tej pieśni. Aby uświęcić czas, należy śpiewać w harmonii z Nim. To jest zadaniem ludzi: podbijać przestrzeń i uświęcać czas" 25 . Heschel powołuje się na Rabina Szymona, który twierdził, że wieczności dostępują nie ci, którzy wymieniają czas na przestrzeń, lecz ci, którzy wiedzą, jak wypełnić swój czas duchem. Istotnym problemem dla wspomnianego Rabina był czas, a nie przestrzeń. Celem człowieka winno być raczej „przekształcenie czasu w wieczność, a nie zapełnianie przestrzeni budynkami, mostami i drogami; rozwiązanie tego problemu leży raczej w studiowaniu Tory i modlitwie niż w geometrii i technice"26. Szabat jest najlepszym sposobem uświęcania i uwieczniania czasu. Dlaczego?

\footnotetext{
21 A.J. Heschel, Szabat, s. 150-151.

22 Ibidem, s. 151.

23 Ibidem, s. 152.

24 Ibidem, s. 153.

25 J. Neusner, N.M. Neusner (red.), An Anthology of Abraham Joshua Heschel, s. 77.

26 A.J. Heschel, Szabat, s. 82.
} 
Dla Żydów wyjątkowe wydarzenia z czasów historycznych były duchowo ważniejsze niż powtarzające się procesy w cyklu przyrody, mimo że od tego zależało ich fizyczne przetrwanie. Podczas gdy bóstwa innych narodów były związane z miejscami lub rzeczami, Bóg Izraela był Bogiem wydarzeń (wyprowadzenie $\mathrm{z}$ niewoli egipskiej, objawienie Tory). Judaizm jest religią czasu mającą na celu uświęcenie czasu. Dla wyznawcy judaizmu czas nie jest niezmienny, powtarzający się. Biblia ukazuje nam zróżnicowany charakter czasu. Każda chwila jest inna i wyjątkowa. Judaizm uczy nas przywiązania do świętości w czasie, przywiązania do świętych wydarzeń, a nie do świętych miejsc. „Szabaty są naszymi wielkimi katedrami, a naszą Najwyższą Świętością jest świątynią, której ani Rzymianie, ani Niemcy nie są w stanie spalić" ${ }^{27}$. Żydowski rytuał można scharakteryzować jako sztukę znaczących form w czasie, jako „architekturę czasu”28. Większość jego obchodów - szabat, nów, festiwale, rok jubileuszowy - zależy od określonej godziny dnia lub pory roku. Źródło wiary natomiast leży w królestwie czasu. W przeciwieństwie jednak do innych świąt, szabat jest całkowicie niezależny od miesiąca i niezwiązany z księżycem. O jego dacie nie decyduje żadne wydarzenie w przyrodzie, takie jak faza księżyca, ale sam akt stworzenia.

Szabat ma na celu celebrowanie czasu, a nie przestrzeni. Sześć dni w tygodniu żyjemy w królestwie przestrzeni. Siódmy dzień polega na tym, aby wejść do królestwa czasu, aby dopasować się do świętości w czasie ${ }^{29}$. Jest to dzień, w którym jesteśmy wezwani do uczestnictwa w tym, co jest wieczne, aby przejść od rezultatów stworzenia do tajemnicy stworzenia, od świata stworzonego do stworzenia świata. W jednym ze swoich dzieł Rabin stwierdził: „Czas jest granicą wieczności” ${ }^{30}$. Na pytanie, czym jest szabat, Heschel odpowiada wprost: „Jest to Duch w formie czasu" ${ }^{31}$. Choć nasze ciała pozostają w świecie przestrzeni, to jednak nasza dusza jest zakorzeniona w tym, co wieczne i święte. W tym kontekście szabat jawi się jako powrót człowieka do swoich korzeni. Ten dzień jest sposobnością do uświęcenia czasu, do wyniesienia tego, co dobre na poziom tego, co święte, uczynienia sacrum z profanum. Heschel podkreśla dobitnie, że „świat powstał w ciągu sześciu dni stworzenia, ale jego przetrwanie zależy od

27 J. Neusner, N.M. Neusner (red.), An Anthology of Abraham Joshua Heschel, s. 79.

28 Ibidem, s. 80.

29 „Wszechświat został stworzony w sześć dni, lecz szczytem kreacji był dzień siódmy. Rzeczy, które powołano do istnienia w sześć dni są dobre, lecz siódmy dzień jest święty. Szabat jest świętością w czasie" - A.J. Heschel, Bóg szukający człowieka, s. 517.

30 A.J. Heschel, Człowiek nie jest sam, s. 175.

31 J. Neusner, N.M. Neusner (red.), An Anthology of Abraham Joshua Heschel, s. 80. 
świętości siódmego dnia. Wspaniałe są prawa rządzące procesami natury. Ale bez świętości nie byłoby ani wielkości, ani natury"32.

Jaka zatem jest różnica między innymi dniami tygodnia, skoro jeden z nich (szabat) można przeżywać tak jakby był ponad czasem? Wydaje się, że różnica pojawia się jedynie w wymiarze duchowym. Struktura fizyczna pozostaje zupełnie nieporuszona. Mądrość rabinów posługuje się tutaj niezwykle trafnym, a przez to wymownym, spostrzeżeniem, że pozostałe dni tygodnia, pozostają do szabatu $\mathrm{w}$ relacji praeparatio, natomiast szabat względem nich występuje jako iluminatio. „Szabat inspiruje, a pozostałe dni są zainspirowane”33. Judaizm uczy, że życie pobożnego Żyda opiera się na ustawicznym oczekiwaniu dnia siódmego.

Tęsknota za Szabatem przez wszystkie dni tygodnia jest formą tęsknoty za wiecznym Szabatem przez wszystkie dni naszego życia. Dąży do zastąpienia pożądania rzeczy w przestrzeni przez pożądanie rzeczy w czasie, ucząc pragnienia siódmego dnia przez wszystkie dni tygodnia ${ }^{34}$.

\section{Właściwy sposób celebracji szabatu}

Heschel nie tyle przekonuje do idei szabatu, nie tyle dowodzi konieczności przestrzegania świętości tego dnia, co raczej ukazuje jego sens i sposób celebracji. Człowiek jest istotą cielesno-duchową. Szabat zatem przeżywamy także w pewnym dualizmie sfer: cielesnej i duchowej. W dzień ten nie dochodzi do rozdźwięku między tym, co zewnętrzne i tym, co wewnętrzne. Nazwano nawet szabat rozkoszą: „rozkoszą dla duszy i rozkoszą dla ciała” ${ }^{35}$. Ten wyjątkowy czas, staje się okazją do jeszcze większej koherencji pomiędzy tymi wymiarami ludzkiej egzystencji. „Wygoda i przyjemność są integralną częścią świętowania Szabatu” "36 Nieco dalej Heschel stwierdza: „Jest to dzień, który uszlachetnia duszę i czyni mądrym ciało" 37 .

Szabat jako dzień wolny jest wykorzystywany przez Żydów do wypoczynku. Uzasadnione jest złączenie tego aspektu ze świętowaniem dnia siódmego, skoro autor natchniony Biblii przekazuje nam jednoznaczną informację o Bożym

\footnotetext{
32 Ibidem, s. 81.

33 A.J. Heschel, Szabat, s. 52.

34 Ibidem, s. 144-145.

35 Ibidem, s. 47.

36 Ibidem, s. 48.

37 Ibidem, s. 51.
} 
wytchnieniu po akcie kreacji. Jaki jest jednak właściwy sens powstrzymywania się tego dnia od pracy? Rzymianie nie rozumiejący idei szabatu uważali, że odpoczynek związany z tym religijnym świętowaniem jest po prostu oznaką żydowskiego próżniactwa. Współcześnie natomiast przeważa pogląd, że wszyscy potrzebujemy choćby jednodniowego odpoczynku, gdyż tracimy siły fizyczne i nie możemy ciągle pracować. Tymczasem, jak zauważa Heschel,

Szabat jest dniem odpoczynku, dniem powstrzymywania się od trudu - wcale nie w celu odzyskania utraconej siły i zdolności do przyszłej pracy. Szabat jest dniem służącym życiu. Człowiek nie jest pociągowym zwierzęciem, a zadaniem Szabatu nie jest podniesienie wydajności jego pracy [...]. To nie Szabat jest dla powszednich dni tygodnia; to dni powszednie są dla Szabatu. Nie jest przerwą, lecz kulminacją życia ${ }^{38}$.

Wynika z tego, że wszystkie inne dni tygodnia są stopniowym przygotowaniem do obchodów tego właśnie dnia. Wszystko obraca się wokół szabatu, jak Ziemia wokół Słońca. Trzeba nam dokonać swoistego przewrotu myślenia na wzór rewolucji kopernikańskiej. Tylko wtedy zrozumiemy miejsce i rolę szabatu w życiu człowieka.

Rabin podkreśla także, że zakazowi pracy towarzyszy błogosławieństwo radości i element świętości. Z szabatem wiążą się bowiem trzy boskie czyny wyrażone słowami: odpoczął, pobłogosławił, uświęcił. Wynika to wprost z Księgi Rodzaju: „A gdy ukończył w dniu szóstym swe dzieło, nad którym pracował, odpoczął dnia siódmego po całym trudzie, jaki podjął. Wtedy Bóg pobłogosławił ów siódmy dzień i uczynił go świętym; w tym bowiem dniu odpoczął po całej swej pracy, którą wykonał, stwarzając" (Rdz 2,2-3). Al Nakawa ${ }^{39}$ - średniowieczny rabin - wprowadza delikatne rozróżnienia dotyczące uczuć towarzyszących świętowaniu. Heschel powołując się na Al Nakawę uważa, że jedynie radość wśród świętości i odpoczynku przynależy do doczesności, natomiast dwa pozostałe wymiary stanowią zadatek świata przyszłego. Dotykając jedynie czasu teraźniejszego, jednoznacznie widzimy, na podstawie tego ujęcia, iż szabat staje się przestrzenią, zapraszającą człowieka do podejmowania Bożej aktywności, wywołującej u człowieka radość. Pod pojęciem Bożej aktywności należałoby jednak rozumieć wszystko to, co prowadzi człowieka do zachowania pełni godności. Wypoczynek nie oznacza ani próżnowania, ani leniuchowania.

38 Ibidem, s. 40-41.

39 Al Nakawa (zm. 1391) - hiszpański myśliciel żydowski, który zginął śmiercią męczeńską. Autor dzieła Menorat ha-Maor, którego skrót opublikowana także w Krakowie w roku 1593. 
Szabat nie jest okazją do rozrywek czy lekkomyślności; nie jest dniem puszczania fajerwerków czy fikania koziołków, ale sposobnością do naprawiania naszego złachmanionego życia; gromadzenia raczej niż trwonienia czasu [...]. Odpoczynek bez ducha jest źródłem deprawacji ${ }^{40}$.

Co ciekawe, samo słowo menucha jest rozumiane właśnie jako odpoczynek, który jednak oznacza coś więcej niż zakaz pracy czy porzucenie wszelkiego wysiłku i codziennego mozołu. Menucha w duchowości żydowskiej jest utożsamiana raczej ze szczęściem, spoczynkiem, pokojem i harmonią.

Jest to stan, w którym człowiek spoczywa, w którym grzesznik przestaje się trapić, a znużony może odetchnąć. Jest stanem, w którym nie ma konfliktów ani walki, nie ma strachu ani nieufności [...]. W późniejszym okresie słowo menucha stało się synonimem życia w świecie przyszłym, życia wiecznego ${ }^{41}$.

W przeżywaniu szabatu nie chodzi zatem o zwykłe powstrzymywanie się od aktywności fizycznej, ale o osiągniecie właściwego stanu ducha, o „zakosztowanie" zbawczej rzeczywistości. Nic nie powinno zakłócać tego stanu ducha. Córka Heschela daje następujące świadectwo: „W naszym domu w czasie Szabatu pewne tematy były omijane - polityka, Holokaust, wojna w Wietnamie podczas gdy inne były szczególnie podnoszone. Przestrzeganie Szabatu to nie tylko powstrzymywanie się od pracy, ale także stwarzanie menuchy, odpoczynku, który jest także celebracją" 42 .

Szabat jest również świętem wolności, ponieważ pozwala człowiekowi uwolnić się od świata przestrzeni, który go zniewala. W tym sensie jest to również doświadczenie przedsmaku nieba. Jest to bowiem

dzień oderwania się od powszedniości, niezależności od zewnętrznych zobowiązań - dzień, w którym zaprzestajemy modlitw do bożków cywilizacji technicznej dzień, w którym nie używamy pieniędzy - dzień zawieszenia broni w ekonomicznej walce $z$ naszymi bliźnimi i z siłami przyrody ${ }^{43}$.

W każdy inny dzień jesteśmy zanurzeni w doczesności, która pochłania nasze siły, zajmuje czas, angażuje wolę i niekiedy zdobywa serce. Według Heschela istnieje konieczność wzniesienia się ku wieczności, wyrwania się z tej matni doczesności, poczucia bycia wolnym. To zniewolenie jawi się jako problem

\footnotetext{
40 A.J. Heschel, Szabat, s. 46.

41 Ibidem, s. 54.

42 Ibidem, s. 18.

43 Ibidem, s. 61.
} 
egzystencjalny, który jesteśmy w stanie zniwelować właśnie w czasie szabatu. Rabin jest przekonany, że

rozwiązanie najbardziej dręczącego problemu ludzkości można osiągnąć nie poprzez odrzucenie cywilizacji technicznej, ale poprzez uzyskanie w jakimś stopniu niezależności od niej [...]. Podczas Szabatu żyjemy tak, jakbyśmy byli niezależni od cywilizacji technicznej: powstrzymujemy się przede wszystkim od wszelkiej aktywności, której celem jest przetwarzanie czy modelowanie rzeczy przestrzeni ${ }^{44}$.

W tradycji rabinistycznej istniały liczne przepisy regulujące wszelkiego rodzaju normy postępowania człowieka, jednak rozległość a nade wszystko detaliczność owej jurysdykcji, często pozostawała poza możliwością wypełnienia prawa nawet przez pobożnego żyda. Dotyczy to także szabatu. Należy jednak mieć na względzie fakt, że judaizm realnie zakłada zbawcze działanie zwykłego czynu. $Z$ tego powodu religia żydowska jest określana jako etyczny monoteizm. Święte nie jest jedynie to, co oddzielone od świata. Chodzi o uświęcenie wszystkiego, o wyniesienie profanum do poziomu sacrum. Bardzo duże znaczenie ma codzienne życie, w którym należy odnajdywać swoje podobieństwo do Boga i naśladować Jego działanie. Heschel podkreśla, że poprzez czyn weryfikuje się nasza wiara. Zatem zbawienia nie osiąga się jedynie na podstawie samej wiary (credo). "Judaizm przeżywa się w czynach, a nie tylko w myślach"45. To czyn stanowi weryfikator świętości oraz postępu na drodze zbliżania się do Boga. W szerszej perspektywie patrząc, świat potrzebuje nie tyle intelektualnego potwierdzenia czy duchowej motywacji, co raczej dobrych uczynków i realnej świętości życia przeżywanego zgodnie z Bożą wolą. W ten sposób wyraża się realizm zbawienia. Nasz ludzki czyn, mówiąc językiem obrazu, ma moc sprowadzić Boga na ziemię, aby odczuć Jego realną obecność. Tym samym wypełnianie konkretnych przepisów prawa przypomina nam o naszej ludzkiej słabości i ukazuje moc Boga. W kontekście rozważań o szabacie Heschel zatem stwierdza:

Pomimo całej idealizacji nie ma niebezpieczeństwa, aby idea Szabatu stała się bajką. Wraz z całą tą romantyczną idealizacją Szabat pozostaje konkretnym faktem, instytucją prawną i ładem społecznym. Nie ma niebezpieczeństwa, że stanie się niewcielonym duchem, jako że duch Szabatu zawsze musi być zharmonizowany $\mathrm{z}$ rzeczywistymi uczynkami, z określonymi działaniami i ograniczeniami [...]. Zadaniem prawa jest oczyścić drogę; zadaniem duszy jest przeczuć ducha ${ }^{46}$.

44 Ibidem.

45 A.J. Heschel, Człowiek szukający Boga, s. 152.

46 A.J. Heschel, Szabat, s. 44. 
Jak widzimy, konkretne przykazania odnoszące się do celebrowania szabatu służyły skupieniu się na Bogu i pełnemu oddaniu się temu, co Boże. Wyrazem tego jest po prostu wypełnienie micwy. Micwa, która w dosłownym tłumaczeniu rozumiana jest jako dobroć, wartość, pobożność czy też świętość, staje się za każdym razem osnową wszelkiego działania pobożnego Żyda. W ten sposób to, co czyni człowiek stanowi duchowe minimum tego, kim jest. Micwa, którą można rozumieć także jak przykazanie lub uczynek spełniający przykazanie, staje się mostem łączącym człowieka z Bogiem. Zatacza bardzo szeroki horyzont, ponieważ ujmuje w swojej istocie zarówno zewnętrzne czyny jak i wewnętrzne motywacje, postawy. Dla Heschela micwa to „modlitwa w formie czynu"47. Takie rozumienie przeżywania szabatu prowadziło poszczególnych rabinów „do ciągłego powiększania systemu praw i reguł przestrzegania ceremonii. Starali się wzbogacić naturę ludzką i uczynić ją godną przebywania w obecności królewskiego dnia"48. Jak przekonuje Heschel, skrupulatne przestrzeganie przykazań nie prowadzi do deifikacji Prawa. Tora wyraźnie mówi, że zachowanie ludzkiego życia stoi ponad Prawem. Rabin nie ma najmniejszej wątpliwości, że "powinno się raczej poświęcić micwę przez wzgląd na człowie$k a$, a nie poświęcać człowieka przez wzgląd na micwę" 49 . Tora służy bowiem zapewnieniu życia zarówno w tym świecie, jak i w świecie przyszłym ${ }^{50}$.

Celebracja szabatu wiąże się niezaprzeczalnie z zakazem wykonywania wielu czynności, które same w sobie są dobre i w inne dni tygodnia dozwolone, a nawet zalecane. Heschel nie zgadza się z pozornym wrażeniem, że szabat pozbawia pobożnego Żyda przyjemności i polega na umartwianiu się. Przeciwnie. Należy ten dzień uświęcać nie tylko całym sercem i całą duszą, lecz także wszystkimi zmysłami. Mówi wprost: „Nazwano Szabat rozkoszą: rozkoszą dla duszy i rozkoszą dla ciała" ${ }^{1}$. Szabat to nie smutek, lecz radość; nie asceza, lecz przyjemność. W tym dniu mamy lepiej się ubierać, spożywać lepsze posiłki, spotykać się z rodziną i przyjaciółmi, spędzać beztrosko czas. Takie rozumienie szabatu odnajdujemy również w tekstach talmudycznych, które przytaczał Heschel: „Uświęcaj Szabat specjalnymi posiłkami, pięknymi strojami; niech twa dusza rozkoszuje się przyjemnościami, a Ja nagrodzę cię za tę przyjemność" 52 . Jak w żaden inny dzień, „wygoda i przyjemność są integralną częścią święto-

47 A.J. Heschel, Moral Grandeur and Spiritual Audacity, s. 114.

48 Ibidem, Szabat, s. 45.

49 Ibidem.

50 Widać tu wyraźne podobieństwo do ewangelicznego nauczania: „To szabat został ustanowiony dla człowieka, a nie człowiek dla szabatu" (Mk 2,27).

51 A.J. Heschel, Szabat, s. 47.

52 Ibidem, s. 49-50. Heschel cytuje tu: T.B., Dewarim Raba 3,1. 
wania Szabatu. Cały i niepodzielny człowiek, wszystkie jego władze muszą brać udział w tym błogosławieństwie" 53 .

Heschel wraz ze swoją rodziną tak celebrował szabat, jak go opisywał. „Moi rodzice razem sprawiali, że napisane słowa stawały się życiem" ${ }^{4}$ - wspomina córka Heschela. On sam powtarzał, że „przygotowanie na święty dzień, jest tak samo ważne jak sam ów dzień" ${ }^{55}$. Pobożny Żyd jest podekscytowany nawet oczekiwaniem na nadejście szabatu.

Obowiązkiem każdego człowieka jest wielka, wielka żarliwość w czynieniu przygotowań na dzień Szabatu, zapał i pilność właściwe człowiekowi, który dowiedział się, że królowa przybywa, aby przenocować w jego domu, albo że przyjeżdża do niego narzeczona ze wszystkimi towarzyszkami [...]. Któż zatem większy jest niż Szabat, narzeczona i królowa zarazem, Szabat rozkoszą zwany. Tysiąc razy bardziej powinien dbać pan domu o przygotowania, choćby miał nawet i stu służących ${ }^{56}$.

Kiedy wybija odpowiednia godzina, wszystko inne przestaje być ważne. Najlepiej opisuje to Susanah Heschel:

Podczas wypełnionych krzątaniną poranków moja matka kupowała produkty, a popołudniami nerwowa atmosfera gęstniała, gdy zabierała się za gotowanie. Ojciec wracał do domu z biura na godzinę lub dwie przed zachodem słońca, aby zatroszczyć się o swoje własne przygotowania. Kiedy zbliżały się ostatnie minuty tygodnia pracy, rodzice byli razem w kuchni, nerwowo usiłując sobie przypomnieć, co mogło wylecieć im z głowy - czy woda w czajniku się zagotowała? Czy blacha (blech) została nałożona na piekarnik? Czy piekarnik jest włączony? I nagle - to był ten czas: dwadzieścia minut przed zachodem słońca. Cokolwiek pozostało niedokończone w kuchni, po prostu zostawialiśmy za sobą, gdy zapalaliśmy świece i błogosławiliśmy przybycie Szabatu ${ }^{57}$.

Nieco dalej córka Rabina dodaje:

Szabatowy obiad przebiegał w lekkiej i nie do końca poważnej atmosferze, był to czas na żarty i droczenie się. Po obiedzie rodzice ucinali sobie drzemkę, a potem piliśmy herbatę i szliśmy na spacer po Riverside Parku, po drugiej stronie ulicy.

53 Ibidem, s. 48.

54 A.J. Heschel, Moral Grandeur and Spiritual Audacity, s. xxix.

55 A.J. Heschel, Szabat, s. 7.

56 Ibidem, s. 113-114.

57 Ibidem, s. 8. 
Tam spotykaliśmy przyjaciół i znajomych odbywających swoje popołudniowe szabatowe przechadzki ${ }^{58}$.

Dla Heschela szabat stanowi centrum żydowskiego życia indywidualnego i społecznego. Skoro judaizm jest przez niego rozumiany jako religia koncentrująca się na świętości w czasie, to szabat jest niczym innym jak architekturą czasu, katedrą wznoszącą się ku wieczności. Uświęcenie szabatu jest istotnym elementem żydowskiego naśladowania Boga oraz drogą odnajdywania Bożej obecności - nie w przestrzeni, lecz w czasie.

Ścisłe podporządkowanie się prawom regulującym przestrzeganie Szabatu nie wystarczy; celem jest tworzenie Szabatu jako przedsmaku raju. Szabat jest metaforą raju i świadectwem Bożej obecności; w naszych modlitwach wyprzedzamy erę mesjańską, która będzie Szabatem, i każdy Szabat przygotowuje nas na to doświadczenie $^{59}$.

\section{Bibliografia}

Heschel A.J., Bóg szukający człowieka, tłum. A. Gorzkowski, Kraków 2007.

Heschel A.J., Człowiek szukający Boga, tłum. V. Reder, Kraków 2008.

Heschel A.J., God in Serach of Man: A Philosophy of Judaism, New York 1955.

Heschel A.J., Man Is Not Alone: A Philosophy of Religion, New York 1951.

Heschel A.J., Szabat, tłum. H. Halkowski, Gdańsk 1994.

Heschel A.J., The Prophets, New York 1962.

Heschel A.J., Who Is Man?, Stanford 1965.

Heschel, A.J., The Sabbath: Its Meaning for Modern Man, New York 1951.

Heschel A.J., Moral Grandeur and Spiritual Audacity, New York 1996.

Neusner J., Neusner N.M. (red.), An Anthology of Abraham Joshua Heschel, Lanham and New York, London 1990.

Sherman F., The Promise of Heschel, Philadelphia-New York 1970.

Szczerbiński W., Abrahama Joshuy Heschela filozofia człowieka, Lublin 2000.

Umen S., Jewish Concepts and Reflections, New York 1962.

Ibidem, s. 12.

59

Ibidem, s. 19. 